\title{
ILMU SEBAGAI METODE DAN PRODUK
}

\author{
Oleh : Suriyati ${ }^{1}$
}

$* * *$

\begin{abstract}
Abstrak
Ilmu merupakan kumpulan pengetahuan sistematis yang merupakan produk dari aktivitas penelitian dengan metode ilmiah / sebagai sistem pengetahuan, ilmu mempunyai obyek material dan obyek formal. Obyek material sering disebut pokok soal (subject matter), sedangkan obyek material dinamakan titik perhatian (focus of interest) atau sikap pikiran (attitude of mind). Lebih lazim, obyek formal dinamakan sudut pandang. Sebagai sistem pengetahuan atau pengetahuan sistematis, ilmu memiliki ciri- ciri empiris, sistematis, obyektif, analitis, dan verifikatif. Ciri empiris mengandaikan pengamatan (observasi) atau percobaan (eksperimen). Ilmu berbeda dari pengetahuan karena ciri sistematis, dan berbeda dari filsafat karena ciri empirisnya. Ciri sistematis berarti bahwa kumpulan pengetahuan-pengetahuan itu memiliki hubunganhubungan ketergantungan dan teratur. Ciri obyektif ilmu berarti bahwa pengetahuan ilmiah bebas dari rasangka perseorangan (personal bias) dan pamrih pribadi. ilmu arus berisi data yang menggambarkan secara tepat gejala-gejala. ilmu berciri analitis artinya ilmu melakukan pemilahan-pemilahan atas pokok soal ke dalam bagian-bagian untuk mengetahui sifat dan hubungan bagian-bagian tersebut. Ciri verifikatif ilmu berarti bahwa tujuan yang ingin dicapai ilmu ialah kebenaran ilmiah. Kebenaran ini dapat berupa kaidah-kaidah atau azas-azas yang universal.
\end{abstract}

Kata Kunci : Ilmu, sebagai metode dan produk

${ }^{1}$ Dosen STAI Muhammadiyah Sinjai 


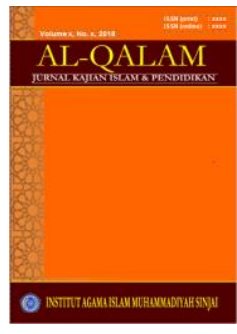

\section{PENDAHULUAN}

\section{A. Latar Belakang}

Tlmu adalah sesuatu yang mulia, yang merupakan anugrah dan nikmat dari Allah swt yang diberikan kepada ummat manusia agar dapat mengangkat derajat kemanusiaannya di dunia dan di akhirat, dan memang ada jaminan dari Allah tentang ketinggian derajat orang-orang yang berilmu, sebagaimana firmanNya dalam QS. Al-Mujadilah (58) : 11

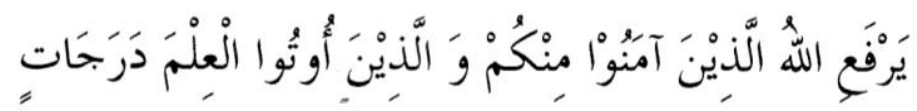

"Allah akan meninggikan orang-orang yang beriman diantaramu dan orangorang yang diberikan ilmu pengetahuan beberapa derajat." ${ }^{2}$

Pengetahuan itu sendiri dimulai dengan rasa ingin tahu, kepastian dimulai dengan rasa ragu-ragu, dan filsafat dimulai dengan kedua-duanya. Berfilsafat didorong untuk mengetahui apa yang kita sudah tahu dan apa yang kita belum tahu. ${ }^{3}$

Ilmu merupakan pengetahuan yang kita gumuli sejak bangku sekolah dasar sampai pendidikan lanjutan dan perguruan tinggi. Berfilsafat tentang ilmu berarti kita berterus terang kepada diri kita sendiri: Apakah sebenarnya yang saya ketahui tentang ilmu ? Apakah ciri-cirinya yang hakiki yang membedakan ilmu dari pengetahuan-pengetahuan yang lainnya yang bukan ilmu ? Bagaimana saya

ketahui bahwa ilmu merupakan pengetahuan yang benar? Kriteria apa yang kita pakai dalam menentukan kebenaran secara ilmiah ? Mengapa kita harus mempelajari ilmu ? Apa kegunaannya yang sebenarnya ${ }^{4}$

Disamping itu masih terdapat bentuk lain dalam usaha manusia untuk mendapatkan pengetahuan yakni wahyu. Ditinjau dari hakikat usahanya, maka dalam rangka menemukan kebenaran, kita dapat bedakan dua jenis pengetahuan. Yang pertama adalah pengetahuan yang didapatkan sebagai hasil

${ }^{2}$ Kementrian Urusan Agama Islam, Wakaf, Da'wah dan Irsyad Kerajaan Saudi Arabia, AlQur'an dan Terjemahannya, (t.cet; Madinah: Percetakan al-Qur'an al-Karim Raja Fahd, 1426H), h. 911.

${ }^{3}$ Jujun S. Suriasumantri. Filsafat Ilmu Sebuah Pengantar Populer, (Cet. XVI; Jakarta: Pustaka Sinar Harapan, 2003M), h. 19.

${ }^{4}$ Ibid., h. 20. 


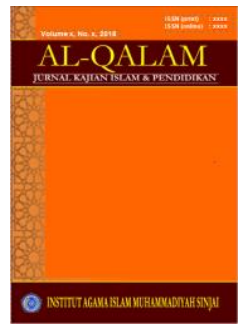

AL-QALAM

Jurnal Kajian Islam \& Pendidikan

Volume 06 No 012014

ISSN (print) : 1858-4152

ISSN (online) : -

Homepage : $\underline{\text { http://journal.iaimsinjai.ac.id/index.php/al-qalam }}$

usaha yang aktif dari manusia untuk menemukan kebenaran, baik melalui penalaran maupun lewat kegiatan lain seperti perasaan dan intuisi. Di pihak lain terdapat pengetahuan yang kedua, yang bukan merupakan kebenaran yang didapat sebagai hasil usaha aktif manusia. Dalam hal ini maka pengetahuan yang didapat itu bukan berupa kesimpulan sebagai produk dari usaha aktif manusia dalam menemukan kebenaran, melainkan berupa pengetahuan yang ditawarkan atau diberikan, umpamanya wahyu yang diberikan Tuhan lewat malaikat dan nabi-nabinya. ${ }^{5}$

Wahyu itu sendiri merupakan produk Tuhan, yang bersifat absolut bagi orang-orang yang beriman kepada-Nya, adapun orang-orang yang tidak beriman maka mereka tidak menganggap wahyu tersebut sebagai sesuatu yang absolut. ${ }^{6}$

\section{PEMBAHASAN}

\section{A. Definisi Ilmu}

Ilmu berasal dari bahasa arab: 'alima, ya'lamu, 'ilman, dengan wazan fa'ila, yaf'alu, fi'lan, yang berarti: mengerti, memahami benar-benar, seperti ungkapan : علم اصموعى درس الفاسفة "Asmu’i telah memahami pelajaran filsafat “. 7 Dalam bahasa Inggris disebut science; dari bahasa latin scienta (pengetahuan) - scire (mengetahui). Sinonim yang paling dekat dengan bahasa Yunani adalah episteme. ${ }^{8}$ Jadi pengertian ilmu yang terdapat dalam kamus bahasa Indonesia adalah pengetahuan tentang suatu bidang yang disusun secara bersistem menurut metode-metode tertentu, yang dapat digunakan untuk menerangkan gejala-gejala tertentu di bidang (pengetahuan) itu. ${ }^{9}$

${ }^{5}$ Ibid., h. 44.

6 KH. Nasaruddin Razak. Pimpinan Wilayah Muhammadiyah. Sulsel, "Wawancara", Makassar, 4 Oktober 2006.

${ }^{7}$ Ahmad warson Munawwir, al-Munawwir; Kamus Arab-Indonewsia, (t. cet; Yogyakarta: Pondok Pesantren al-Munawwir Krapyak Yogyakarta, 1984), h. 1036

${ }^{8}$ Amsal Bakhtiar, Filsafat Ilmu, (t. cet; Jakarta: PT. Raja Grafindo Persada, 2006), h. 12.

${ }^{9}$ Wihadi Admojo, et. Al., Kamus Bahasa Indonesia, (cet. I; Jakarta: Balai Pustaka, 1998), h. 324 . 
Adapun definisi ilmu menurut para ahli ${ }^{10}$, diantaranya adalah:

- Muhammad Hatta, mendefinisikan ilmu adalah pengetahuan yang teratur tentang pekerjaan hukum kausal dalam suatu golongan masalah yang sama tabiatnya, baik menurut kedudukannya tampak dari luar, maupun menurut bangunannya dari dalam. ${ }^{11}$

- Ralph Ross dan Ernest Van Den Haag, mengatakan ilmu adalah yang empiris, rasional, umum dan sistematik, dan keempatnya serentak. ${ }^{12}$

- Karl Pearson, mengatakan ilmu adalah lukisan atau keterangan yang komprehensif dan konsisten tentang fakta pengalaman dengan istilah yang sederhana. ${ }^{13}$

- Ashley Montagu, Guru Besar Antropolog di Rutgers University menyimpulkan bahwa ilmu adalah pengetahuan yang disusun dalam satu sistem yang berasal dari pengamatan, studi dan percobaan untuk menentukan hakikan prinsip tentang hal yang sedang dikaji. ${ }^{14}$

- Harsojo, Guru Besar Antropolog di Universitas Padjajaran, menerangkan bahwa ilmu adalah:

1. Merupakan akumulasi pengetahuan yang disistemasikan.

2. Suatu pendekatan atau metode pendekatan terhadap seluruh dunia empiris, yaitu dunia yang terikat oleh faktor, ruang dan waktu, dunia yang pada prinsipnya dapat diamati oleh panca indra manusia.

3. Suatu cara menganalisis yang mengizinkan kepada ahli-ahlinya untuk menyatakan suatu proposisi dalam bentuk: "Jika..., maka...". ${ }^{15}$

- Afanasyef, seorang pemikir marxist bangsa Rusia mendefinisikan ilmu adalah pengetahuan manusia tentang alam, masyarakat, dan pikiran. Ia memikirkan alam dan konsep-konsep, kategori dan hukum-hukum, yang

${ }^{10}$ Amsal Bakhtiar, op. cit., h. 15.

${ }^{11}$ Endang Saifuddin Anshari. Ilnui, Filsafat, dan Agama, (Cet. VII; Surabaya: Bina Ilmu, 1981 M), h. 47.

${ }^{12}$ Ibid., h.47.

${ }^{13}$ Ibid., h.47.

${ }^{14}$ Ibid., h.48.

${ }^{15}$ Ibid., h.48-49. 


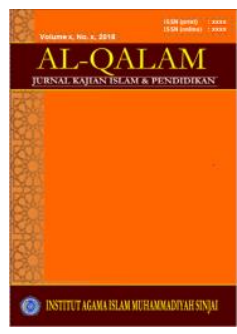

AL-QALAM

Jurnal Kajian Islam \& Pendidikan

Volume 06 No 012014

ISSN (print) : 1858-4152

ISSN (online) : -

Homepage : $\underline{\text { http://journal.iaimsinjai.ac.id/index.php/al-qalam }}$

ketetapannya dan kebenarannya diuji dengan pengalaman praktis. ${ }^{16}$

Dari keterangan para ahli tentang ilmu diatas, Amsal Bakhtiar menyipulkan bahwa ilmu adalah sebagian pengetahuan yang mempunyai ciri, tanda, syarat tertentu, yaitu sistematik, rasional, empiris, universal, objektif, dapat diukur, terbuka, dan kumulatif (bersusun timbun). Mulyadhi Kartanegara berpendapat bahwa objek ilmu tidak mesti selalu empiris, karena realitas itu tidak hanya yang empiris bahkan yang tidak empiris lebih luas dan dalam dibandingkan dengan yang empiris. Karena itu, dia memasukkan teologi adalah ilmu, yang sama dengan ilmu-ilmu lainnya. ${ }^{17}$

\section{B. Ilmu sebagai Metode dan Produk}

Perkembangan dan kemajuan peradaban manusia tidak bisa dilepaskan dari peran ilmu. Bahkan perubahan pola hidup manusia dari waktu ke waktu sesungguhnya berjalan seiring dengan sejarah kemajuan dan perkembangan ilmu. Kemajuan ilmu dan teknologi dari masa ke masa adalah ibarat mata rantai yang tidak terputus satu sama lain.

\section{Ilrnu sebagai metode}

Ilmu sebagai metode adalah merupakan suatu proses penerapan ilmu dengan penjabaran yang terperinci dalam rangka menemukan pengetahuan yang lebih luas. Pengetahuan yang diperoleh oleh manusia melalui akal, indra, dan lain-lain mempunyai metode tersendiri dalam teori pengetahuan, ${ }^{18}$ diantaranya adalah:

Metode Induktif; Induksi yaitu suatu metode yang menyimpulkan pernyataan-pernyataan hasil observasi disimpulkan dalam suatu pernyataan yang lebih umum. ${ }^{19}$ Dalam induksi, setelah diperoleh pengetahuan, maka akan dipergunakan hal-hal lain, seperti ilmu mengajarkan kita bahwa kalau logam dipanasi ia mengembang, bertolak dari teori ini kita akan tahu bahwa logam lain kalau dipanasi juga akan mengembang. Dari contoh diatas bisa diketahui bahwa induksi tersebut memberikan suatu pengetahuan yang disebut juga

${ }^{16}$ Ibid., h. 49

${ }^{17}$ Amsal Bakhtiat, op. cit., h. 16

${ }^{18}$ Ibid., h. 152.

${ }^{19}$ Tim Dosen Filsafat Ilmu UGM, Filsafat Ilmu, (t. Cet; Yogyakarta: Liberty Yogyakarta, 1996), h. 109 


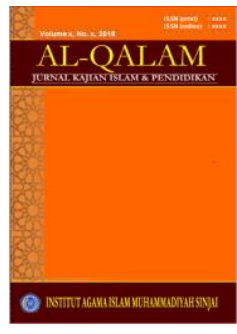

AL-QALAM

Jurnal Kajian Islam \& Pendidikan

Volume 06 No 012014

ISSN (print) : 1858-4152

ISSN (online) : -

Homepage : $\underline{\text { http://journal.iaimsinjai.ac.id/index.php/al-qalam }}$

dengan pengetahuan sintetik. ${ }^{20}$

Metode Deduktif; Deduksi ialah suatu metode yang menyimpulkan bahwa data-data empirik diolah lebih lanjut dalam suatu sistem pernyatan yang runut. ${ }^{21}$ Hal-hal yang harus ada dalam metode deduktif ialah adanya perbandingan logis antara kesimpulan-kesimpulan itu sendiri. Contohnya: jika penawaran besar, harga akan turun. Karena penawaran beras besar, maka harga beras akan turun. ${ }^{22}$

Metode Positivisme; Metode ini dikeluarkan oleh August Comte (17891857). Metode ini berpangkal dari apa yang telah diketahui, yang faktual. yang positif. Ia mengenyampingkan segala uraian atau persoalan diluar yang ada sebagai fakta. Apa yang diketahui secara positif, adalah segala yang tampak dan segala gejala. Dengan demikian metode ini dalam bidang filsafat dan ilmu pengetahuan dibatasi kepada bidang gejala-gejala saja. ${ }^{23}$

Metode Kontemplatif; Metode ini mengatakan adanya keterbatasan indra dan akal manusia untuk memperoleh pengetahuan, sehingga objek yang dihasilkan pun akan berbeda-beda harusnya dikembangkan suatu kemampuan akal yang disebut dengan intuisi. Pengetahuan yang diperoleh lewat intuisi ini bisa diperoleh dengan cara berkontemplasi seperti yang dilakukan oleh al-Ghazali. ${ }^{24}$ Intuisi dalam tasawuf disebut dengan ma'rifah yaitu pengetahuan yang datang dari Tuhan melalui pencerahan dan penyinaran. ${ }^{25}$

Metode Dialektis; Dalam filsafat, dialektika mula-mula berarti metode tanya jawab untuk mencapai kejernihan filsafat. Metode ini diajarkan oleh Socrates, namun Plato mengartikannya diskusi logika. Kini dialektika berarti tahap logika, yang mengajarkan kaidah-kaidah dan metode-metode penuturan, juga analisis sistematik tentang ide-ide untuk mencapai apa yang terkandung

\footnotetext{
${ }^{20}$ Amsal Bakhtiar, op.cit., h. 153-154

${ }^{21}$ Tim Dosen Filsafat Ilmu UGM, Loc. Cit.

${ }^{22}$ Amsal Bakhtiar, op. cit., h. 153-154

${ }^{23}$ Ibid., h. 154.

${ }^{24}$ Ibid., h. 155.

${ }^{25}$ Al-Ghazali, al-Mungidh min al-Dhalal, diterjemahkan Masyhur Abadi, Setitik Cahaya Dalam Kegelapan, (Surabaya: Prograssif, 2002M), h. 32
} 


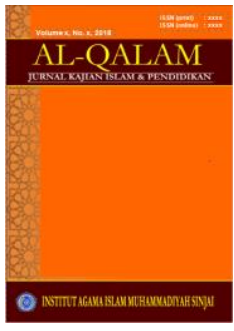

AL-QALAM

Jurnal Kajian Islam \& Pendidikan

Volume 06 No 012014

ISSN (print) : 1858-4152

ISSN (online) : -

Homepage : $\underline{\text { http://journal.iaimsinjai.ac.id/index.php/al-qalam }}$

dalam pandangan. ${ }^{26}$

\section{Ilmu sebagai produk}

Caries Siregar menyatakan: "Ilmu adalah proses yang membuat pengetahuan." Adapun Jujun S. Suriasumantri dalam buku Ilmu dalam Perspektif menulis: "...ilmu lebih bersifat merupakan kegiatan daripada sekedar produk yang siap dikonsumsikan". ${ }^{27}$

Pengetahuan berkembang dari rasa ingin tahu, yang merupakan ciri khas manusia karena manusia adalah satu-satunya makhluk yang mengembangkan pengetahuan secara sungguh-sungguh. Binatang juga mempunyai pengetahuan, namun hanya terbatas untuk kelangsungan hidupnya. Dengan ilmu yang dimiliki oleh manusia, maka manusia mempergunakannya sebagai suatu produk untuk mengembangkan ilmu tersebut menjadi pengetahuanpengetahuan dan hasil karya yang bisa diambil manfaatnya.

Tentang tujuan ilmu pengetahuan dalam ilmu pengetahuan modern ialah bahwa ilmu pengetahuan bertujuan menundukkan alam, alam dipandangnya sebagai sesuatu untuk dimanfaatkan dan dinikmati semaksimal mungkin. Dalam hubungan ini Nasr (Sayyed Hossein Nasr) mengemukakan bahwa akibat yang akan terjadi dari pandangan demikian, alam diperlakukan oleh manusia modern seperti pelacur, mengambil manfaat dan kepuasan darinya tanpa rasa kewajiban dan tanggung jawab apapun. ${ }^{28}$

Perkembangan ilmu pengetahuan di zaman kontemporer ditandai dengan berbagai teknologi canggih. Teknologi dan informasi termasuk salah satu yang mengalami kemajuan yang pesat. Mulai dari penemuan komputer, satelit komunikasi, imternet dan lain-lain. Manusia dewasa ini memiliki mobilitas yang begitu tinggi, karena pengaruh teknologi komunikasi dan informasi. ${ }^{29}$ Bidang ilmu lain juga mengalami kemajuan pesat, sehingga terjadi spesialisasispesialisasi ilmu yang semakin tajam. Ilmuwan kontemporer mengetahui hal yang sedikit tetapi secara mendalam. Ilmu kedokteran pun semakin menajam dalam spesialis dan subspesialis. Demikian bidang-bidang

\footnotetext{
${ }^{26}$ Amsal Bakhtiar, op. cit., h,. 155-156

${ }^{27}$ Ibid., h. 91

${ }^{28}$ Ibid., h. 160

${ }^{29}$ Ibid., h. 161
} 


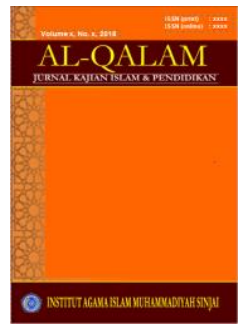

AL-QALAM

Jurnal Kajian Islam \& Pendidikan

Volume 06 No 012014

ISSN (print) : 1858-4152

ISSN (online) : -

Homepage : $\underline{\text { http://journal.iaimsinjai.ac.id/index.php/al-qalam }}$

ilmu lain disamping kecendrungan lain adalah sintesis antara bidang ilmu satu dengan lainnya, sehingga dihasilkan bidang ilmu baru seperti bioteknologi dan psikolinguistik. ${ }^{30}$ Hal ini merupakan implementasi ilmu sebagai suatu produk yang dikembangkan oleh para ilmuwan.

Produk-produk ilmu sangat mermanfaat bagi kelangsungan hidup umat manusia. Dan merupakan kenyataan yang tak bisa dipungkiri bahwa peradaban manusia sangat berhutang kepada ilmu. Ilmu telah banyak mengubah wajah dunia seperti hal memberantas penyakit, kelaparan, kemiskinan, dan berbagai wajah kehidupan yang sulit lainnya. Dengan kemajuan ilmu juga manusia bisa merasakan kemudahan lainnya seperti transportasi, pemukiman, pendidikan, komunikasi, dan lain sebagainya. Singkatnya ilmu merupakan sarana (juga produk -Pen-) untuk embantu manusia dalam mencapai tujuan hidupnya. ${ }^{31}$

Kemudian timbul pertanyaan, apakah ilmu selalu merupakan berkah dan penyelamat bagi manusia? Dan memang sudah terbukti, dengan kemajuan ilmu pengetahuan, manusia dapat menciptakan (memproduk) berbagai bentuk teknologi. Misalnya pembuatan bom yang pada awalnya untuk mempermudah kerja manusia, namun kemudian dipergunakan untuk hal-hal yang bersifat negatif yang menimbulkan malapetaka bagi manusia itu sendiri. Di sinilah ilmu harus diletakkan secara proposional dan memihak pada nilai-nilai kebaikan dan kemanusiaan. Sebab, jika ilmu tidak berpihak kepada nilai-nilai, maka yang terjadi adalah bencana dan malapetaka. ${ }^{32}$

\section{KESIMPULAN}

Berdasarkan uraian di atas maka, penulis mengambil beberapa kesimpulan diantaranya:

1. Defenisi ilmu adalah, sebagian pengetahuan yang mempunyai ciri, tanda, syarat tertentu, yaitu sistematik, rasional, empiris, universal, objektif, dapat diukur, terbuka, dan kumulatif (bersusun timbun). Dan objek ilmu tidak mesti selalu empiris, karena realitas itu tidak hanya yang empiris bahkan yang tidak

\footnotetext{
${ }^{30}$ Tim Dosen filsafat Ilmu UGM, op. cit., h. 52

${ }^{31}$ Amsal Bakhtiar, op. cit., h. 162

${ }^{32}$ Ibid., h. 162
} 
empiris lebih luas dan dalam dibandingkan dengan yang empiris. Karena itu teologi juga adalah ilmu, yang sama dengan ilmu-ilmu lainnya.

2. Ilmu sebagai metode adalah merupakan suatu proses penerapan ilmu dengan penjabaran yang terperinci dalam rangka menemukan pengetahuan yang lebih luas. Pengetahuan yang diperoleh oleh manusia melalui akal, indra, dan lainlain mempunyai metode tersendiri dalam teori pengetahuan, di antaranya adalah: Metode Induktif, Metode Deduktif, Metode Positivisme, Metode Kontemplatif, Metode Dialektis.

3. Ilmu adalah proses membuat pengetahuan, dan lebih bersifat kegiatan daripada sekedar produk yang siap untuk dikonsumsikan. Dengan ilmu yang dimiliki oleh manusia, maka manusia mempergunakannya sebagai suatu produk untuk mengembangkan ilmu tersebut menjadi pengetahuanpengetahuan dan hasil karya yang bisa diambil manfaatnya. Llmu harus diletakkan secara proposional dan memihak pada nilai-nilai kebaikan dan kemanusiaan. Sebab, jika ilmu tidak

\section{DAFTAR PUSTAKA}

Admojo, Wihadi. et al., Kamus Bahasa Indonesia. Cet. I; Jakarta: Balai Pustaka, $1998 \mathrm{M}$.

A1-Ghazali. Al-Munqidh min al-Dhalal. Diterjemahkan oleh Masyhur Abadi dengan judul Setitik Cahata Dalam Kegelapan. t. cet; Surabaya: Progressif, $2002 \mathrm{M}$.

Anshari, Endang Saifuddin. Ilmu, Filsafat, dan Agama. Cet. VII; Surabaya: Bina Ilmu, $1981 \mathrm{M}$.

Bakhtiar, Amsal. Filsafat Ilmu. t. cet; Jakarta: PT. Raja Grafindo Persada, 2006M.

Kementrian Urusan Agama Islam, Wakaf, Da'wah dan Irsyad Kerajaan Saudi Arabia. Al-Qur'an dan Terjemahannya. t.cet; Madinah: Percetakan alQur'an al-Karim Raja Fahd, 1426 H.

Munawwir, Ahmad Warson. Al-Munawwir; Kamus Arab-Indonesia. t. cet; Yogyakarta: Pondok Pesantren al-Munawwir Krapyak Yogyakarta, 


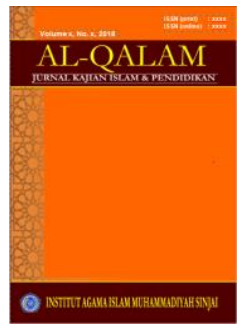

AL-QALAM

Jurnal Kajian Islam \& Pendidikan

Volume 06 No 012014

ISSN (print) : 1858-4152

ISSN (online) : -

Homepage : http://journal.iaimsinjai.ac.id/index.php/al-qalam

1984M.

Suriasumantri, Jujun S. Filsafat Ilmu Sebuah Pengantar Populer. Cet. XVI; Jakarta: Pustaka Sinar Harapan, 2003 M.

Tim Dosen Filsafat Ilmu UGM. Filsafat ilmu. t. cet; Yogyakarta: Liberty Yogakarta, $1996 \mathrm{M}$. 